\title{
Developing the Reference Books of Center, Area and Group Learning Models Based on Environment and Thematic in Early Childhood Education
}

\author{
Hendra Sofyan ${ }^{1, *}$, Evita Anggereini ${ }^{2}$ \\ ${ }^{1}$ Early Childhood Education Program, FKIP, Universitas Jambi, Indonesia \\ ${ }^{2}$ Biology Study Program, FKIP, Universitas Jambi, Indonesia
}

Received August 7, 2019; Revised September 23, 2019; Accepted September 27, 2019

Copyright $\bigcirc 2019$ by authors, all rights reserved. Authors agree that this article remains permanently open access under the terms of the Creative Commons Attribution License 4.0 International License

\begin{abstract}
The learning at Kindergarten in all over Indonesia uses Area learning model, centre learning model, and group learning model. In fact, the reference book of these three learning models does not exist yet. The purpose of this research and development is to produce valid and proper reference book of Area learning model, Center learning model, and Group learning model as the handbook and guidelines for Lecturers of PAUD (Early Childhood Education), PAUD teachers, and PAUD students. The research method used was the R\&D (Research and Development), which referred to the ADDIE (Analysis, Design, Develop, Implementation, and Evaluation) model. Data analysis was obtained from three analysis stages, such as material questionnaire validation, design questionnaire validation, and users' responses analysis (teacher and college students) towards the reference book. The results of material validation were conducted two times. The result of material validation the first step is in "good" criteria". The second validation obtains criteria "very good". Likewise, the responses from the teacher, for the reference book material are in the "very good" category, and the reference book design is in the "good" category. These results show that the reference book developed is proven valid and proper to be used in learning at school.
\end{abstract}

Keywords Center Learning Model, Area and Group

\section{Introduction}

The implementation of the learning process in kindergartens throughout Indonesia uses a variety of models, including Area learning model, the Center learning model, and Group learning model [1]. Learning by using these learning models that are designed based on the curriculum greatly help teachers and students in the learning process to be more focused and concentrated [2]. Besides, the learning model is also in accordance with the Weekly Activity Design (RKM) program, Weekly Learning Implementation Plan (RPPM), Daily Activity Design (RKH) and Daily Learning Implementation Plan (RPPH). The teacher combines the learning process with the thematic, so that it is appropriate to the local environment of the child and the development of Early Childhood [3].

When carrying out the daily learning process, the teachers are required to prepare all the tools used in the learning process, uniquely the Daily Activity Plan, because based on this design the teacher can take action in the learning process in one day.

In reality, there is no specific guide for Area learning models, Center learning models, and Group learning models yet, while Early Childhood Education Lecturers, Kindergarten teachers and students find that it is difficult to find reference books for the learning [1]. The lack of success in improving early childhood development is thought to occur, because teachers are less than optimal in using or designing learning processes that can improve aspects of development in children, such as motor, cognitive, language, social-emotional, and moral elements in accordance with themes that can be applied in the learning process in kindergarten $[4,5]$.

The research findings were obtained by the researcher when conducting initial research on kindergarten teachers in Jakarta, Padang and Bandung. Besides, preliminary information was also obtained by the researcher from Early Childhood Education (PAUD ) students at Jambi universities as well as teachers who continued PAUD education. Almost all respondents who were met, they claimed to have difficulty in implementing Area model learning, Center learning models and Group learning 
models. Also, there are no general and specific guidelines so that developing learning models are various forms in compiling and preparing the learning models.

\subsection{Research Objective}

Based on the problems outlined earlier, the researcher felt the need to develop a valid and feasible reference book, both in terms of material and design. This reference book is expected to be used as a guide for teachers in implementing Area learning models, Center learning models and Group learning models. This textbook combines the learning process with an environmental and thematic approach so that it suits the needs of the child and the growth of early childhood. Specifically, the objectives of this study are:

1. Developing validity reference book material based on expert assessments.

2. Developing validity reference book design based on expert assessment.

3. Developing validity reference book (RPPM \& RPPH) components based on expert assessments.

4. Developing an appropriate reference book material based on teacher responses

5. Developing an appropriate reference book design based on teacher responses.

\section{Method of Implementation}

\subsection{Development Model}

The development model used refers to the ADDIE model (Analysis, Design, Develop, Implementation, and Evaluation) [6]. The ADDIE model chosen in this development research is based on several reasons, namely, this model is a procedural model, which is a descriptive model, shows precise and careful steps to produce a product.

\subsection{Development Procedure}

Based on the ADDIE development model, the stages of research in the development of Area learning, Center learning and Group-based development learning through environmental and thematic approaches are as follows:

1. Analysis is analysing needs through field observations and literature studies.

2. Design is the design of a new product development device. Design reference book development at this stage carried out several steps, namely: Scheduling, book design specifications, and implementation of development in accordance with the learning area implementation plan, learning centre implementation plan and the learning group implementation plan.

3. Development, which is where at this stage, the development of reference book products is made
Products developed at this stage are validated by learning tools experts. This validation is done before the reference book product is tested and carried out several times. If there are products that are not yet valid, then a revision is made until the reference book product is declared valid.

4. Implementation is the stage for implementing a reference book product that contains a learning area design, learning centres and group learning that is being developed. The design of the reference book product, which has been validated by the validator, is tested on the group's test subjects as users of the products that had been developed. The group test was conducted in all kindergartens in Jambi City consisting of 8 sub-districts.

5. Evaluation (Evaluation) is the process of showing reference book products containing Area learning designs, Center learning and Group learning that are developed successfully and in accordance with those targeted at the analysis stage. The results of the evaluation are significant for the improvement of the reference book product developed.

\subsection{Time and Sample of Research}

This research was conducted in 12 kindergartens in Jambi Province in 2017. The selection of 12 kindergartens is in Jambi Province because in their learning process, they have used Area Learning Models, Center Learning Models and Group Learning Models. In this study, the researcher involved three experts in assessing the material, design and reference book components developed and included 100 teachers to respond to the developed reference books. Expert assessment is conducted by 3 experts, who come from the field of early childhood education, the field of learning media and the field of research and evaluation of education. The Validator was chosen based on experience and education level, at least 5 years completed doctoral program. Teachers selected as samples using Stratified random sampling, which is a sampling technique with regard to a level (strata) of the population element. The Strata used are years of working and level of education.

\subsection{Technical Analysis of Data}

Data results obtained from teacher validation and response were analysed using descriptive statistics. The results of the descriptive analysis are then converted to the effective learning results table below.

Analysis of this research data was in the form of a validation questionnaire and user response questionnaire, namely as follows:

1) Analyzing the results of the validation from the initial validation of the product until the product can be stated to be feasible (good) by the material expert and media design expert. 
2) Calculating the average percentage of positive responses shown from the questionnaire. Calculates the percentage score of each question, using the formula:

$$
\mathrm{RS}=\frac{f}{n} \times 100 \%
$$

Description:

$\mathrm{RS}=$ Percentage of teacher responses,

$\mathrm{f}=$ number of scores for each sub-variable,

$\mathrm{n}=$ maximum number of scores

From the results of these calculations, the perception of experts and teachers on the validity and feasibility of reference book products tested can be concluded from the criteria (very good, good, poor, very poor) which has the highest percentage. More specific criteria can be seen in the following table 1

Table 1. Guidelines for respondent response conventions

\begin{tabular}{|c|c|}
\hline Percentage of Obtained Scores (\%) & Effectivity \\
\hline $\mathrm{X}>76$ & Very Good \\
\hline $50<\mathrm{X} \leq 75$ & Good \\
\hline $25<\mathrm{X} \leq 50$ & Poor \\
\hline $\mathrm{X} \leq 25$ & Very Poor \\
\hline
\end{tabular}

\section{Result and Discussion}

\subsection{Data Description}

3.1.1. Results Analysis of the Materials Reference Validation for the Center Learning, Area Learning and Group Learning Models

Research Objective 1: Develop valid reference book material Based on expert assessments.

The results of the validation analysis done by experts on the developed reference book material show that the validation process II is better than the results of the validation I. It can be seen from the increasing score and percentage of each validation stage. Complete results of each stage of validation are shown in the table below:

Table 2. Percentage of material expert validation on reference books

\begin{tabular}{|c|c|c|c|}
\hline No & Indicator & $\begin{array}{c}\text { Validation } \\
\text { Stage 1 }\end{array}$ & $\begin{array}{c}\text { Validation } \\
\text { Stage 2 }\end{array}$ \\
\hline 1 & Relevance & 61.11 & 86.11 \\
\hline 2 & Accuracy & 62.5 & 100 \\
\hline 3 & $\begin{array}{c}\text { Completeness of } \\
\text { Presentation }\end{array}$ & 75 & 81.25 \\
\hline 4 & $\begin{array}{c}\text { Systematics of } \\
\text { Presentation }\end{array}$ & 62.5 & 75 \\
\hline 5 & $\begin{array}{c}\text { Compatibility of } \\
\text { Presentation }\end{array}$ & 70 & 90 \\
\hline 6 & Way of Presentation & 75 & 100 \\
\hline 7 & Language Suitability & 75 & 87.5 \\
\hline \multicolumn{2}{|c|}{ Total } & 68.73 & 88.55 \\
\hline
\end{tabular}

Validation by material experts is done 2 (two) times. From the table of expert validation results of the 1st material (first) to the reference book show an average score of 68.73 , which means that it is in a good category. In the second (second) expert material validation process on the reference book, an average score of 88.55 was obtained, which means that it is in a very good category. The total evaluation for each stage of validation is based on indicators of relevance, accuracy, completeness of the presentation, systematic of presentation, compatibility of the presentation, way of presentation, and suitability of the language.

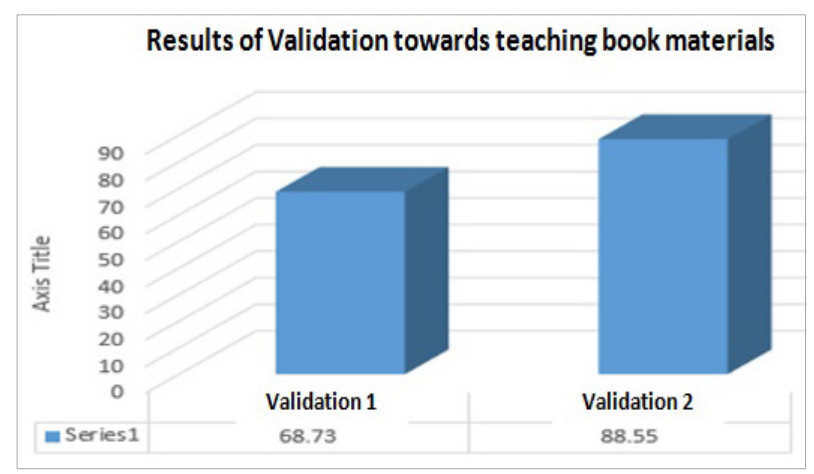

Figure 1. Diagram comparison of the percentage of material validation at each validation stage

3.1.2. Results Analysis of the Book Reference Validation for the Center Learning, Area Learning and Group Learning Models

Research Objective 2: Develop a valid reference book design based on expert assessment.

The results of the validation analysis by the expert on the developed reference book design show that the validation process II is better than the results of the validation I. It can be seen from the increasing score and percentage of each validation stage. Complete results of each stage of validation are shown in the table below:

Table 3. Percentage of design validation on each indicator's reference book

\begin{tabular}{|c|c|c|c|}
\hline No & Indicator & $\begin{array}{c}\text { Validation } \\
\text { Stage 1 }\end{array}$ & $\begin{array}{c}\text { Validation } \\
\text { Stage 2 }\end{array}$ \\
\hline 1 & Typography & 68.75 & 87.5 \\
\hline 2 & Picture Display & 75 & 87.5 \\
\hline 3 & Organisation & 81.25 & 100 \\
\hline 4 & $\begin{array}{c}\text { Reference Book } \\
\text { Presentation }\end{array}$ & 70.83 & 95.83 \\
\hline \multicolumn{2}{|c|}{ Total } & 73.96 & 92.71 \\
\hline
\end{tabular}

Validation by experts of the reference book design is done 2 (two) times. From the table of results of expert validation on the design of the 1 st (first) reference book to the reference book, the average score which was obtained is 73.96 and is referred in good category. In the expert validation process of the second (second) reference book design, an average value of 92.71 is obtained, and the 
criteria is very good. The total evaluation for each stage of validation is based on typography indicators, image display, layout and reference book presentation.

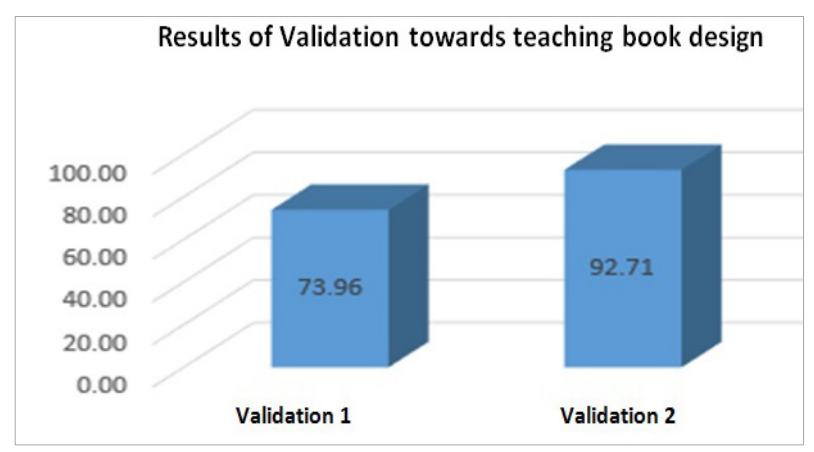

Figure 2. Comparison diagram of the percentage of design validation results to the reference books

\subsubsection{Analysis of the Component Validation Results (RPPM \& RPPH) of Learning Center, Area and Group Models}

Research Objective 3: Develop a valid reference book (RPPM \& RPPH) components based on expert assessments

RPPM \& RPPH validation is integrated into the learning tools that will be validated and analysed by the material experts and carried out 2 (two) times. From the 1st (first) validation result table, a score of 67 is obtained with a percentage of $64.35 \%$, which means that it is in the "good" criteria. In the second (second) validation, the total score is 80 , with a percentage of $75 \%$ which referred to as the "good" criteria. There is an increase between the first validation and the second validation. In general, there was an increase of $10.65 \%$, from $64.35 \%$ from the first validation to $75 \%$.

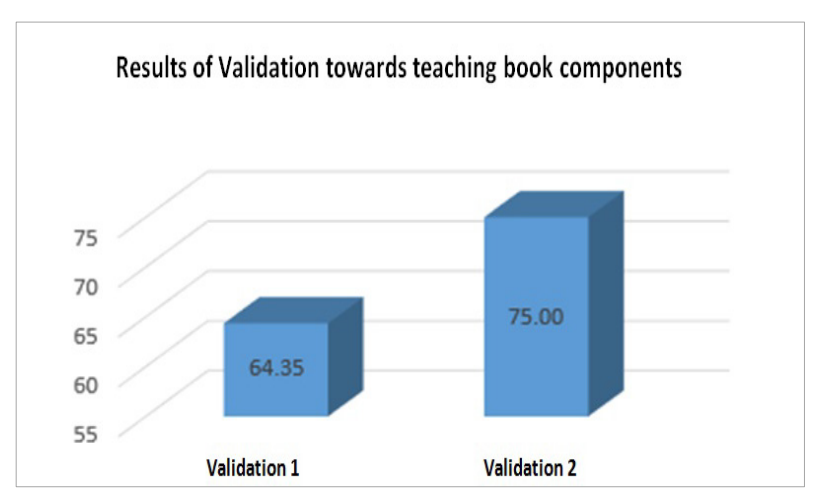

Figure 3. Comparison diagram of the results of RPPM \& RPPH validation

\subsubsection{Analysis of the Teacher's Response to the Reference} Materials for the Center, Area and Group Learning Models

Research Objective 4: Develop appropriate reference book material based on teacher responses.

The results of the analysis of teacher responses to the developed reference book material show that the material in the reference book is generally included in the excellent category. The complete results of each validation stage are shown in the table below:

Table 4. Diagram percentage of Teacher's response to the reference book material

\begin{tabular}{|c|c|c|c|}
\hline No & Indicators & Score (\%) & Category \\
\hline 1 & Relevance & 74.91 & Good \\
\hline 2 & Accuracy & 74.39 & Good \\
\hline 3 & $\begin{array}{c}\text { Completeness of } \\
\text { Presentation }\end{array}$ & 82.05 & Very Good \\
\hline 4 & $\begin{array}{c}\text { Systematics of } \\
\text { Presentation }\end{array}$ & 72.58 & Good \\
\hline 5 & $\begin{array}{c}\text { Compatibility of } \\
\text { Presentation }\end{array}$ & 75 & Good \\
\hline 6 & Way of Presentation & 76.34 & Very Good \\
\hline 7 & Language Suitability & 76.07 & Very Good \\
\hline 8 & Legibility & 70.8 & Good \\
\hline & Total & 75,26 & Very Good \\
\hline
\end{tabular}

In the indicator of relevance, $74.91 \%$ is obtained, which is classified as "good" criteria. Then in the accuracy indicator, $74.39 \%$ and is classified as a "good" criterion. Furthermore, the completeness of the presentation obtained $82.05 \%$ and included in the category of "very good". In serving systematic, 72.58 is obtained with the "good" category. Besides, the indicators of the suitability of the presentation obtained $75 \%$ and included in the criteria of "good". In the way of presentation, 76.34 is obtained and is included in the "very good" criteria. On language suitability and language readability, they are $76.7 \%$ and $70.80 \%$, respectively. Both of these indicators fall into the "Very good" and "good" categories. In general, for the teacher's response to the material/content of the book, a percentage of $75.26 \%$ was obtained, which included the "very good" criteria.

3.1.5. Analysis of the Teacher's Response to the Design of the Reference Centre, Area and Group Learning Models

Research Objective 5: Developing an appropriate reference book design based on teacher responses.

The results of the analysis of the teacher's response to the reference book design that was developed show that the material in the reference book is generally in the good category. Complete results of each stage of validation are shown in the table below:

Table 5. Percentage of Teacher responses to the design of the reference book

\begin{tabular}{|c|c|c|c|}
\hline No & Indicator & Score & Category \\
\hline 1 & Typography & 70.46 & Good \\
\hline 2 & Picture Display & 76.2 & Very Good \\
\hline 3 & Organisation & 70.50 & Good \\
\hline 4 & Reference Book Presentation & 72.98 & Good \\
\hline \multicolumn{2}{|c|}{ Total } & 72.21 & Good \\
\hline
\end{tabular}


In typography, indicators obtained $70.46 \%$, which is classified as "good" criteria. Then the picture display indicator obtained $76.20 \%$ and classified into the criteria of "very good". Furthermore, the layout of the images (Organisation) obtained $70.50 \%$ or in the category of "good". Then, in addition to that, the reference book presentation obtained $72.98 \%$ with the category "good". In general, the teacher's response to the contents of the book obtained $72.21 \%$, which is included in the criteria of "good".

\section{Discussion}

The novelty of the results of this study takes the form of a reference book about Area learning, Center learning and Group learning. Research related to the area learning model, centre learning and group learning has been carried out by various researchers who are researching about early childhood.

Research conducted by Sofyan [1] on area-based learning models shows that learning areas provide more opportunities for students to choose/do their activities according to their interests. The learning is designed to meet the specific needs of children and respect cultural diversity and emphasise the learning experience for each child, the choice of activities and activity centres as well as family participation in the learning process.

Group learning model is a learning pattern where children are divided into groups (usually into three groups) where each group is doing different activities $[4,7,8]$. If in the change of groups there are children who have completed their assignments faster than their peers, then the child can continue other activities as long as there is still place for the child in the other groups.

Research conducted by Nurfitriana [9] shows that the centre learning model can develop children's abilities in practising prayer worship through several play steps and habituation in congregational prayer when playing at the Center. Other research was conducted by Putri [10], which shows that the management of learning centres and circles can improve the quality of Center learning in PAUD institutions. In this study, the uniqueness of the development of learning models in kindergarten uses the Area learning model, and the complete Learning Center is packaged in the form of a reference book.

Development based learning models through environmental and thematic approaches using Area learning models, Center learning and Group learning were also examined $[1,11]$. The results of his research show that this learning model can improve the development of six-year-old children in social-emotional, cognitive, moral, language, gross motor and excellent motor development.

Previous studies have shown that the area learning model, learning centre and group learning can improve the ability and development of children. However, there is no comprehensive guidance in the form of reference books, which makes this research is essential. The results of the development of this reference book are proven to be valid and feasible so that they can be used as a guide in the Area learning model, Center learning and Group learning.

\section{Conclusions}

The developing of teaching materials (reference books) for the learning models of Center, Area and Group learning centre areas and groups through the stages of developing the ADDIE model has proven to be valid and feasible to use. The results are based on the Validation of the Center, Area and Group Learning reference book materials as well as the Design validation of the reference book and Validation of the Learning Implementation Plan. An indication of the eligibility of a reference book is based on the Teacher's Response to the reference books, which are divided based on responses to the material and responses to the design. Based on the results of validation by the expert and the teacher's response, the product development of teaching materials (books) Weekly Learning Implementation Plan (RPPM) \& Daily Learning Implementation Plan (RPPH) is suitable for use in learning at schools. From these findings, it is expected that PAUD Lecturers, PAUD Teachers and PAUD Students can find out, understand, and implement Area learning models, Center learning and development-based group learning models through environmental and thematic approaches to improve the development of all aspects of early childhood by utilizing books references that have been developed by researcher.

\section{REFERENCES}

[1] Sofyan, H.: 'Perkembangan Anak Usia Dini dan Cara Praktis Peningkatannya’, Jakarta: Infomedika, 2014

[2] Latif, M.: 'Orientasi Baru Pendidikan Anak Usia Dini Teori \& Aplikasi’ (Prenada Media, 2016. 2016)

[3] Suyadi, D.: 'Implementasi dan Inovasi Kurikulum PAUD 2013', Bandung: ROSDA, 2014

[4] Hurlock, E.B.: 'Perkembangan Anak edisi keenam', Terjemahan oleh Med Meitasari Tjandrasa. Jakarta: Erlangga, 1978

[5] Jamaris, M.: 'Orientasi baru dalam psikologi pendidikan', Bogor: Ghalia Indonesia, 2013

[6] Branch, R.M.: 'Instructional design: The ADDIE approach' (Springer Science \& Business Media, 2009. 2009)

[7] Kostelnik, M.J., Spalding, G., Howe, D., Payne, K., and Rohde, B.: 'Teaching young children using themes' (Good Year Books, 2008. 2008) 
[8] Mutiah, D.: 'Psikologi bermain anak usia dini', in Editor (Ed.) $)^{\wedge}$ Eds.): 'Book Psikologi bermain anak usia dini' (Prenada Media Group, 2010, edn.), pp.

[9] Nurfitriana, N.: 'Pendidikan Anak Usia Dini dalam Al-Qur'an', MIDA: Jurnal Pendidikan Dasar Islam, 2018, 1, (2), pp. 103-119

[10] Putri, A.P.: 'Manajemen pembelajaran sentra dan lingkaran: studi multikasus pada lembaga pendidikan anak usia dini Anak Saleh dan Taman Harapan di Kota Malang', SKRIPSI Jurusan Administrasi Pendidikan-Fakultas Ilmu Pendidikan UM, 2009

[11] Hanum, R.: ' Mengembangkan Komunikasi Yang Efektif Pada Anak Usia Dini', Bunayya: Jurnal Pendidikan Anak, 2017, 3, (1), pp. 45-58 